\title{
Aerial biomass allometric models for Prosopis affinis Spreng. in native Espinal forests of Argentina
}

\author{
Silvana M. J. Sione ${ }^{1}$, Hernán J. Andrade-Castañeda ${ }^{2}$, Silvia G. Ledesma ${ }^{1}$, Leandro J. Rosenberger ${ }^{1}$, \\ José D. Oszust ${ }^{1} \&$ Marcelo G. Wilson ${ }^{3}$ \\ ${ }^{1}$ Universidad Nacional de Entre Ríos/Facultad de Ciencias Agropecuarias. Oro Verde, Entre Ríos, Argentina. E-mail: silsion@fca.uner.edu.ar (Corresponding \\ author) - ORCID: 0000-0002-2119-0363; sledesma@fca.uner.edu.ar - ORCID: 0000-0002-9264-1766; javierosenberger@gmail.com - ORCID: 0000- \\ 0003-1016-1644; joszust@fca.uner.edu.ar - ORCID: 0000-0003-2668-3201 \\ ${ }^{2}$ Universidad del Tolima/Facultad de Ingeniería Agronómica/Grupo de Investigación PROECUT. Ibagué, Colombia. E-mail: hjandrade@ut.edu.co - \\ ORCID: 0000-0002-3398-294X \\ ${ }^{3}$ Instituto Nacional de Tecnología Agropecuaria/Estación Experimental Agropecuaria Paraná. Oro Verde, Entre Ríos, Argentina. E-mail: wilson.marcelo@inta.gob.ar - \\ ORCID: 0000-0002-1214-1041
}

\begin{abstract}
Estimation of carbon stored in forest ecosystems requires accurate biomass prediction tools. The objective of this study was to determine the individual aerial biomass of Prosopis affinis and its distribution by component, to develop allometric models for the estimation of biomass and to estimate biomass expansion factors $(\mathrm{BEF})$ in native forests of Entre Ríos (Argentina). Dendrometric variables on 30 individuals of different diameter classes were measured. Values of total aerial biomass and component biomass (trunk, branches larger than $5 \mathrm{~cm}$ in diameter and branches smaller than $5 \mathrm{~cm}$ + leaves, flowers and fruits) were determined using the destructive method. Different models were developed, and the best models were selected according to the adjusted coefficient of determination $\left(\mathrm{R}^{2} \mathrm{adj}\right)$, mean squared prediction error, the Akaike information and Bayesian information criteria and the Furnival index. The variables crown area, diameter at breast height and total height were the best estimators of total aerial biomass and component biomass of $P$. affinis. The single-variable model based on the basal diameter has a very good predictive capacity for total aerial biomass, resulting in a simple model of great practicality. The BEF was significantly different among diameter classes, with mean values between 2.28 and 4.90. The highest values corresponded to individuals with trunk diameters larger than $25 \mathrm{~cm}$. The models developed in this work present high precision $\left(\mathrm{R}^{2} \mathrm{adj} . \geq 0.94\right)$ for the prediction of total aerial biomass of $P$. affinis and can be applied in the native forest area of the province of Entre Ríos (Argentina).
\end{abstract}

Key words: carbon reservoir, ecosystems, Fabaceae

\section{Modelos alométricos de biomassa aérea para Prosopis affinis Spreng. em florestas nativas Espinal da Argentina}

RESUMO: A estimativa do carbono armazenado nos ecossistemas florestais requer ferramentas precisas para prever a biomassa. Objetivou-se nesse estudo determinar a biomassa aérea individual de Prosopis affinis e sua distribuição por componente; desenvolver modelos alométricos para prever a biomassa, e estimar os fatores de expansão da biomassa (FEB) em florestas nativas de Entre Ríos (Argentina). Foram medidas variáveis dasométricas em 30 indivíduos de diferentes classes de diâmetro e determinada a biomassa aérea total e por componente (tronco, ramos com mais de $5 \mathrm{~cm}$ de diámetro, e ramos menores que $5 \mathrm{~cm}+$ folhas, flores e frutos) pelo método destrutivo. A seleção dos modelos com melhor ajuste foi feita de acordo com o coeficiente de determinação ajustado ( $\left.\mathrm{R}^{2} \mathrm{adj}\right)$, o erro médio quadrático de predição, os Critérios de Informação de Akaike e Bayesiana e o Índice de Furnival. As variáveis área da copa, diâmetro à altura do peito e altura total são os melhores estimadores da biomassa aérea total e por componente de P. affinis. O modelo de variável única baseado no diâmetro basal tem uma capacidade preditiva elevada de biomassa aérea, resultando em uma ferramenta simples de grande praticidade. A FEB oscilou entre 2,28 e 4,90, sendo significativamente diferente entre as classes diamétricas. Os maiores valores corresponderam aos indivíduos com diâmetros de tronco maiores que $25 \mathrm{~cm}$. Os modelos desenvolvidos neste trabalho apresentam elevada precisão ( $\mathrm{R}^{2}$ adj. $\geq 0,94$ ) para a predição da biomassa aérea total de $P$. affinis, e podem ser aplicados na área de florestas nativas de Entre Ríos (Argentina).

Palavras-chave: reservatório de carbono, ecosistemas, Fabaceae 


\section{INTRODUCTION}

The changes in land use are one of the main processes associated with global change. In this context, the deforestation and degradation of forest systems has contributed significantly to the increase of greenhouse gas emissions. The environmental service provided by native forests and agroforestry systems that act as carbon sinks reduces the carbon dioxide concentration in the atmosphere.

A large part of forest carbon (C) reserves is found in the biomass of the woody species, so the methods that estimate stored carbon are focused on the biomass stock of these species (IPCC, 2014). The total aerial biomass of woody species can be estimated by allometric models of biomass or volume based on the variables of standing individuals (Andrade Castañeda et al., 2014). Biomass equations must be specific for each species and each part of the tree (Risio Allione, 2012). If no existing biomass models are suitable, it is possible to resort to biomass expansion factors (BEF) for this task, which are coefficients that use the volume or total biomass of tree trunks to obtain the total biomass of the tree; these coefficients are useful for estimating total tree biomass and stored $\mathrm{C}$ from information generated by forest inventories (Somogyi et al., 2006).

Prosopis affinis Spreng. is an arboreal species of the Fabaceae family that is characteristic of forests of the Espinal phytogeographic province (Entre Ríos, Argentina). At the national level, there are few studies that aim to obtain biomass and BEF estimation models in native tree species of different forest ecosystems (Conti et al., 2008; Gyenge et al., 2009; Iglesias \& Barchuk, 2010; Risio Allione, 2012; Gaillard de Benítez et al., 2010, 2014).

When estimating $\mathrm{C}$ stored in native forest ecosystems, it is a priority to have local and specific predictions models of tree biomass as an application tool. Therefore, the aims of this study were as follows: i) to determine the individual aerial biomass of Prosopis affinis and its distribution by tree component; ii) to develop allometric models for individual aerial biomass estimation; and iii) to estimate biomass expansion factors in native Espinal forests (Entre Ríos, Argentina).

\section{Material ANd Methods}

The study area belongs to the native forests area of the Entre Ríos province (Argentina), corresponding to the Espinal phytogeographic province, District Nandubay (Cabrera, 1976). The local climate is humid, with a thermal amplitude of $13{ }^{\circ} \mathrm{C}$ and a daily mean annual temperature of $18.5^{\circ} \mathrm{C}$. Regional vegetation is characterized by semixerophilous forests dominated by P. affinis and Vachellia caven Mol. Molina, accompanied by Prosopis nigra Griseb., Prosopis alba Griseb., and Celtis ehrenbergiana (Klotzsch) Liebm. These forests are characterized by their heterogeneity, resulting from the ecological conditions and the history of use and management to which they have been subjected, mainly cattle breeding and feeding, based on natural grasses growing in these systems.

The Espinal area has been subjected to changes in land use, having experienced in recent decades a significant reduction in its forest area. Annual deforestation rates of the order of $0.96 \%$ have been estimated (Sabattini et al., 2016). The dominant driver of deforestation is the advance of the agricultural frontier. The remaining forests present current symptoms of degradation resulting from the anthropogenic management to which they have been subjected for productive purposes (Sabattini et al., 2016).

The study was developed in the native forests area of the Paraná Department ( $31^{\circ} 36^{\prime} 40^{\prime \prime}$ S, $60^{\circ} 0^{\prime} 22^{\prime}$ ' W, $82 \mathrm{~m}$ a.s.l.). This zone presents a wide diversity of soils corresponding to Vertisols, Mollisols and Alfisols orders. The soils in 69\% of the area belong to the Vertisols order. The site where the study was carried out has typical Hapludert soils, characterized by an argillic horizon of low permeability. The climax community is a forest of $P$. affinis and V. caven, complemented with P. nigra and C. ehrenbergiana. The average tree density is 1112 individuals ha ${ }^{-1}$, and $69 \%$ of these trees are P. affinis.

Thirty individuals of $P$. affinis were selected, as recommended by Segura Madrigal \& Andrade Castañeda (2008), and were distributed in five diametric classes, 5-10, 10-15, 15-20, 20-25 and $>25 \mathrm{~cm}$, as determined by trunk diameter measured at $15 \mathrm{~cm}$ above ground $\left(\mathrm{D}_{15}\right)$; each diameter class included six individuals. The sizes of the selected plants were representative of the size range of $P$. affinis individuals found in the study region.

The biomass was quantified by the destructive method in February 2017, coinciding with the physiological stage of maximum foliage expression. In each selected individual, before cutting it, the following dendrometric variables were measured: trunk diameter at $15 \mathrm{~cm}$ above the ground $\left(D_{15}\right)$, at $30 \mathrm{~cm}$ above the ground $\left(\mathrm{D}_{30}\right)$, and at breast height $-1.30 \mathrm{~m}$ above the ground (DBH); basal area (ba); total height $(\mathrm{H})$; trunk height until the first bifurcation (ht); crown larger diameter (Dc) and its perpendicular (crown smaller diameter, dc); and crown height (hc). For the diameter measurements, Mantax callipers were used. An individual's height was determined with a telescopic rod. The crown area (ca) was calculated as $\pi(\mathrm{dc}+\mathrm{dc})^{2} / 4$, and the crown height was calculated as the difference between $\mathrm{H}$ and the height of the first green branch, as proposed by Gaillard de Benitez et al. (2014).

Trees were cut at ground level, and biomass was separated into the following three components: trunk (considered from trunk base to the first important branch, Bt); large branches with diameter $>5 \mathrm{~cm}(\mathrm{Blb})$; and small branches (diameter $\leq 5 \mathrm{~cm}$ ) + leaves, flowers and fruits (Bsbl). The fresh weight of each fraction was estimated in the field with a hook scale of $300 \mathrm{~kg}$ (resolution $100 \mathrm{~g}$ ). For dry matter determination, aliquots or subsamples were extracted. Three slices were selected from the trunk (basal, central and superior); five slices of different diameters were taken from the large branches, and from the small branches + leaves, flowers and fruits, another three aliquots of $\sim 250 \mathrm{~g}$ were taken. The aliquots were weighed in the field with a precision analytical scale (resolution $0.1 \mathrm{~g}$ ) and transported to the laboratory, where they were introduced to an oven at $105{ }^{\circ} \mathrm{C}$ until constant weight to determine the average dry matter content of each component.

The total aerial biomass of each individual (B) was calculated as the sum of the dry weight of all the components. Subsequently, the biomass percentage of each component was determined within each individual as the quotient between the dry weight of each component and the total aerial biomass of the individual. 
The BEF values were estimated as the quotient between the total aerial biomass (B) and trunk biomass (Bt), expressed as $\mathrm{kg}$ of dry biomass per individual. Finally, the BEF average for each diameter class was calculated.

The normality (Shapiro-Wilk test) and homogeneity of the variances of the data were verified, and the non-normal variables were log-transformed. An analysis of variance (ANOVA) was carried out to evaluate the variation in the BEF among diameter classes.

The correlations between the proportion of biomass of each component and the $\mathrm{D}_{15}$, and between this variable and $\mathrm{BEF}$ values were analysed. A Fisher test $(\alpha=0.05)$ was used to check for significant differences in BEF and in the contribution of the trunk to the total biomass among the different diameter classes.

To develop the allometric models, $\mathrm{D}_{15}, \mathrm{D}_{30}, \mathrm{DBH}, \mathrm{ba}, \mathrm{H}, \mathrm{ht}$, $\mathrm{hc}$ and ca were used as predictor variables. The parameters $\mathrm{B}$, $\mathrm{Bt}, \mathrm{Blb}$ and $\mathrm{Bsbl}$ were considered dependent variables. Based on the analysis of normality, independence and homogeneity of the variances of these variables, it was decided to use transformations (natural logarithms). Subsequently, Pearson correlation coefficients ( $r$ ) between total and component biomass values ( $\mathrm{B}, \mathrm{Bt}, \mathrm{Blb}$ and $\mathrm{Bsbl}$ ) and predictor variables were obtained to identify the capability of explaining the biomass of these latter variables.

The selected predictor variables were those with highest correlation coefficients with the dependent variables. Using the simple and multiple linear regression modules of Statgraphics Centurion $\mathrm{XVI}^{\oplus}$ version 16.1 (StatPoint Technologies Inc., 2010), predictive regression functions were generated for each of the dependent variables.

The models were selected according to criteria of Andrade Castañeda et al. (2014), as follows: highest adjusted $R^{2}$ ( $R^{2}$ adj), lowest square error (SE), mean prediction quadratic error (MPQE), lowest Akaike information criterion (AIC), lowest Bayesian information criterion (BIC) and lowest Furnival Index (IF) (Furnival, 1961). Each indicator was rated from best to worst in each model, and the best model was considered the one that had the best combined rating of those criteria (Andrade Castañeda et al., 2014).

The Durbin-Watson statistic was calculated with a confidence level of $95 \%$ to determine if there was serial autocorrelation in the residuals. An analysis of estimated vs observed and residuals for the selected models was carried out. The statistical analyses were performed using the software Statgraphics Centurion XVI ${ }^{\circledR}$ (version 16.1).

\section{Results AND Discussion}

The sampled individuals presented a total aerial biomass that varied between 5.26 and $385.53 \mathrm{~kg}$ tree $^{-1}$. Figure 1 shows the participation of components in the total aerial biomass (\%) of $P$. affinis individuals. The largest biomass accumulation was concentrated in the fraction Bsbl, followed by the trunk (41.9 $\pm 6.8 \%$ and $32.8 \pm 10.7 \%$, respectively).

Biomass partitioned by component showed different trends depending on $\mathrm{D}_{15}$ values. The trunk percentage in total biomass showed a negative linear trend, decreasing as $\mathrm{D}_{15}$ increased (determination coefficient $\mathrm{R}^{2}=0.66$ ). This relative participation of the trunk showed significant differences between diametric

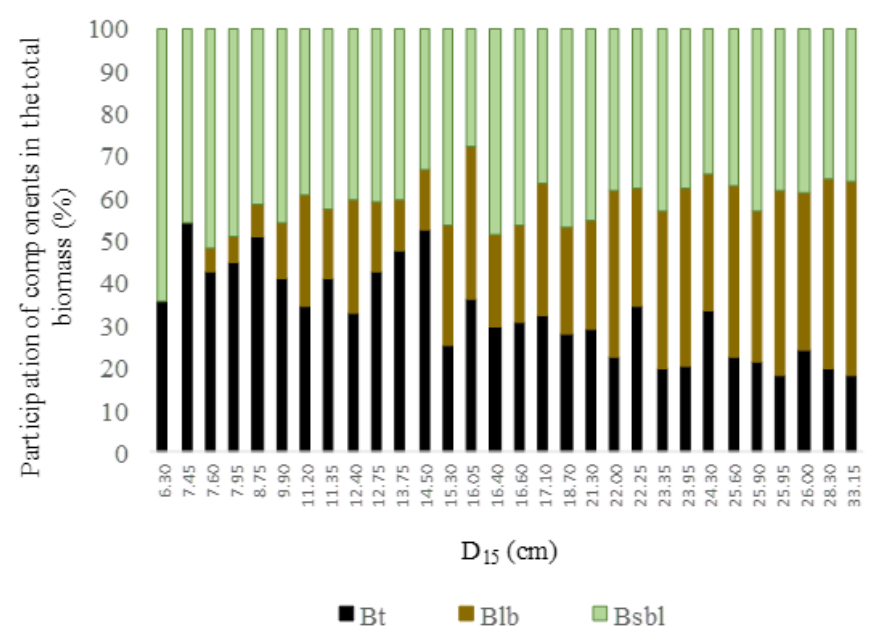

$\mathrm{Bt}$ - Trunk biomass; Blb - Large branches biomass; Bsbl - Small branches + leaves + flowers and fruits biomass; $D_{15}$ - Trunk diameter at $15 \mathrm{~cm}$ above the ground

Figure 1. Participation of components in the total aerial biomass - B (\%) of Prosopis affinis individuals

classes $(\mathrm{p}<0.0001)$, with the lowest mean values corresponding to the class $>25 \mathrm{~cm}(20.6 \%)$, while individuals of the $5-10 \mathrm{~cm}$ class presented the highest percentages $(44.7 \%)$. A tendency to increase the proportions of large branches was observed with the increase of $D_{15}(r=0.82)$, showing existing significant differences between diameter classes $(\mathrm{p}<0.0001)$, with mean values that ranged between 5.4 and $41.1 \%$. The highest values corresponded to individuals with $\mathrm{D}_{15}>25 \mathrm{~cm}$. The $\mathrm{Bsbl}$ relative participation in the total biomass varied between 38.3 and $49.9 \%$, being significantly higher $(\mathrm{p}=0.0115)$ in individuals with smaller diameters.

Gaillard de Benítez et al. (2014) also observed that the percentages of leaves and small branches of $P$. nigra decreased with the increase of basal diameter, while the percentage contribution of the large branches to the total biomass increased. However, in contrast with this work, they observed that the trunk contribution to total biomass increased with increasing basal diameter.

The analysis of aerial biomass distribution by component within each individual, indicates that $P$. affinis invests most of its resources in the development of minor branches, leaves and fruits, followed by the trunks (41.9 and $32.8 \%$ on mean, respectively). This agrees with the findings of Risio Allione (2012), who indicated that Prosopis caldenia (species with physiognomy similar to P. affinis) stores the largest amount of biomass in the crown (46.35\%).

A linear increase was observed in BEF values with the increase of $D_{15}\left(R^{2}=0.72\right)$. Significant differences were observed between classes $(\mathrm{p}<0.0001)$, with mean values that ranged between 2.3 and 4.9. The highest values corresponded to the class $>25 \mathrm{~cm}$, being significantly higher $(\mathrm{p}<0.0001)$ than the rest of the diametric classes (Table 1). This behaviour was due to the increasing relative participation of the fraction Blb as the DB increases and the lower participation of the trunk in the total biomass.

BEF values vary according to species, growth rate, age and dimensional structure of stands, so its determination for the different species that make up a forest is a priority. The BEF values obtained in this work are significantly higher than those cited for other tree species. The high BEF values 
Table 1. Biomass expansion factors of Prosopis affinis by diameter class, in native forests of Espinal (Entre Ríos, Argentina)

\begin{tabular}{cccc|}
\hline \multirow{2}{*}{$\begin{array}{c}\text { Diametric class } \\
\left.\mathbf{(}_{\mathbf{1 5}}, \mathbf{c m}\right)\end{array}$} & \multicolumn{3}{c|}{ Biomass expansion factors (BEF) } \\
\cline { 2 - 4 } & Mean values & SE & $\begin{array}{c}\text { Confidence } \\
\text { intervals (95\%) }\end{array}$ \\
\hline $5-10$ & $2.25 \mathrm{a}$ & 0.12 & $1.98-2.53$ \\
$10-15$ & $3.06 \mathrm{a}$ & 0.18 & $2.66-3.46$ \\
$15-20$ & $3.56 \mathrm{~b}$ & 0.50 & $1.39-5.73$ \\
$20-25$ & $4.55 \mathrm{~b}$ & 0.31 & $3.78-5.31$ \\
$>25$ & $5.28 \mathrm{C}$ & 0.27 & $1.90-8.66$ \\
\hline
\end{tabular}

Same letters indicate not significant differences (LSD Fisher $\mathrm{p} \leq 0.05$; Analysis based on the transformed values to logarithm). D15 - Trunk diameter at $15 \mathrm{~cm}$ above the ground $\mathrm{cm}$; SE - Standard error

obtained for the highest diameter classes are a consequence of the physiognomy of the species, characterized by a lower participation of trunk to total biomass in individuals of larger diameters and a further relative growth of the crown compared to that of the trunk. Risio Allione (2012), in a study of $P$. caldenia in Pampa Argentina forests, observed that the highest biomass percentage was in the crown, while the fraction corresponding to the trunk in the total biomass was the lowest (19\%). In contrast to the present study, this research also considered the root biomass. Although these authors did not report BEF estimates, it is expected that with these percentages of trunk participation in total biomass, similar values to those found in the present work would be obtained.
It is important to note the great variability of BEF values reported in the literature, depending mainly on the species under study. Bautista-Hernández \& Torres-Pérez (2003) observed values of 3.7 for Manilkara zapota and 21.3 for Caesalpinia platyloba (both, tropical forest species). In another study, Domínguez-Cabrera et al. (2009) obtained BEF values of 1.4 and 1.5 for Pinus teocote and Quercus sp., respectively.

Total aerial biomass was highly correlated with $\mathrm{D}_{15}, \mathrm{D}_{30}$, $\mathrm{DBH}$, ba and ca $(0.92<\mathrm{r}<0.98, \mathrm{p}<0.01)$, and moderately correlated with hc $(\mathrm{r}=0.70, \mathrm{p}<0.01)$ and $\mathrm{H}(\mathrm{r}=0.64, \mathrm{p}<$ 0.01 ). In contrast, ht showed a low correlation with biomass (Table 2). Trunk biomass was better explained by independent variables $\left(\mathrm{D}_{15}, \mathrm{D}_{30}, \mathrm{DBH}\right.$, ba and ca) than by the biomass of other components (Blb and Bsbl) (Table 2).

In general, these results are similar to those reported by Risio Allione (2012) for P. caldenia. These authors determined that basal area presented the highest correlation with the total individual biomass $(\mathrm{r}=0.86)$ and the trunk biomass $(\mathrm{r}=0.85)$, large branches biomass $(r=0.76)$ and small branches $(0.67<$ $\mathrm{r}<0.77)$. The basal diameter also showed high correlations with all fractions of the biomass $(0.64<\mathrm{r}<0.83)$. The lowest correlation coefficients corresponded to crown height and crown diameter.

Seven models were developed for the estimation total aerial biomass (Table 3), all with $\mathrm{R}^{2} \mathrm{adj} \geq 0.97$.

Table 2. Correlation (Pearson coefficient $-r$ ) among aerial biomass (total and by components) and dendrometric variables in Prosopis affinis individuals, in native forests of Espinal (Entre Ríos, Argentina)

\begin{tabular}{lccccccccc}
\hline \multicolumn{1}{c}{ Biomass $\left(\mathrm{kg} \mathrm{tree}^{-1}\right)$} & $\mathbf{D}_{15}$ & $\mathbf{D}_{30}$ & $\mathbf{D B H}$ & ba & ca & H & hc & ht \\
Trunks & 0.97 & 0.97 & 0.97 & 0.98 & 0.96 & 0.69 & 0.70 & -0.39 \\
Large branches & 0.88 & 0.88 & 0.90 & 0.96 & 0.92 & 0.58 & 0.66 & -0.49 \\
Small branches + leaves + flowers and fruits & 0.92 & 0.92 & 0.93 & 0.97 & 0.96 & 0.65 & 0.71 & -0.44 \\
Total aerial (aboveground) & 0.92 & 0.92 & 0.93 & 0.98 & 0.95 & 0.64 & 0.70 & -0.46 \\
\hline
\end{tabular}

All values of the Pearson correlation coefficient greater than 0.6 presented a $\mathrm{p}<0.01 ; \mathrm{D}_{15}$ - Trunk diameter at $15 \mathrm{~cm}$ above the ground, $\mathrm{cm} ; \mathrm{D}_{30}-$ Trunk diameter at $30 \mathrm{~cm}$ above the ground, cm; DBH - Diameter at breast height, cm; ba - Basal area, $\mathrm{m}^{2}$; ca - Crown area, $\mathrm{m}^{2} ; \mathrm{H}$ - Total height, $\mathrm{m}$; hc - Crown height, $\mathrm{m}$; and ht- Trunk height, $\mathrm{m}$

Table 3. Best-fit models to estimate total aerial biomass and the biomass of the different components of Prosopis affinis individuals in native forests of Espinal (Entre Ríos, Argentina)

\begin{tabular}{|c|c|c|c|c|c|c|c|}
\hline Biomass & Model & $R^{2}$ adj & SE & MPQE & AIC & BIC & FI \\
\hline \multirow{5}{*}{ Trunk } & $\operatorname{Ln}(B t)=-2.82+2.04 * \operatorname{Ln}\left(D_{30}\right)$ & 0.99 & 0.01 & 0.01 & -48.6 & -44.4 & 1.5 \\
\hline & $\operatorname{Ln}(B t)=-3.05+2.08 * \operatorname{Ln}\left(D_{15}\right)$ & 0.99 & 0.01 & 0.02 & -39.9 & -35.8 & 1.5 \\
\hline & $\operatorname{Ln}(B t)=-1.98+1.81 * \operatorname{Ln}(\mathrm{DBH})$ & 0.97 & 0.03 & 0.04 & -13.3 & -9.1 & 2.6 \\
\hline & $\operatorname{Ln}(B t)=-1.76+0.91 * \operatorname{Ln}(\mathrm{ba})$ & 0.96 & 0.03 & 0.04 & -13.3 & -9.1 & 2.6 \\
\hline & $\operatorname{Ln}(B t)=0.47+0.13 * D_{15}$ & 0.94 & 0.06 & 0.07 & 4.22 & 8.42 & 3.7 \\
\hline \multirow{6}{*}{$\begin{array}{l}\text { Large } \\
\text { branches }\end{array}$} & $\operatorname{Ln}(B \mid b)=-7.29+3.26 * \operatorname{Ln}(D B H)+0.90 * \operatorname{Ln}(H)$ & 0.98 & 0.06 & 0.08 & 7.4 & 12.8 & 2.8 \\
\hline & $\operatorname{Ln}(\mathrm{Blb})=-6.70+2.86 * \operatorname{Ln}(\mathrm{DBH})+0.73 * \operatorname{Ln}(\mathrm{H})+0.27{ }^{*} \operatorname{Ln}(\mathrm{ca})$ & 0.98 & 0.06 & 0.09 & 6.7 & 13.3 & 2.7 \\
\hline & $\operatorname{Ln}(B \mid b)=-7.01+0.23 * H+3.27 * \operatorname{Ln}(D B H)$ & 0.98 & 0.06 & 0.08 & 7.6 & 12.9 & 2.8 \\
\hline & $\operatorname{Ln}(B \mid b)=-6.47+0.19 * H+2.87 * \operatorname{Ln}(D B H)+0,28 * \operatorname{Ln}(\mathrm{ca})$ & 0.98 & 0.06 & 0.09 & 6.9 & 13.6 & 2.8 \\
\hline & $\operatorname{Ln}(B \mid b)=-6.70+3.50 * \operatorname{Ln}(D B H)$ & 0.97 & 0.10 & 0.10 & 11.9 & 15.9 & 3.5 \\
\hline & $\operatorname{Ln}(B \mid b)=-8.53+3.99 * \operatorname{Ln}\left(D_{30}\right)$ & 0.96 & 0.11 & 0.13 & 21.7 & 25.7 & 1.2 \\
\hline \multirow{6}{*}{$\begin{array}{l}\text { Small branches } \\
+ \text { leaves + } \\
\text { flowers and fruits }\end{array}$} & $\operatorname{Ln}(B s b \mid)=-2.01+0.96 * \operatorname{Ln}(D B H)+0.71 * \operatorname{Ln}(H)+0.65 * \operatorname{Ln}(\mathrm{ca})$ & 0.97 & 0.03 & 0.04 & -11.6 & -4.6 & 3.6 \\
\hline & $\operatorname{Ln}(B s b l)=-1.79+0.19 * H+0.96 * \operatorname{Ln}(D B H)+0.64 * \operatorname{Ln}(\mathrm{ca})$ & 0.98 & 0.03 & 0.04 & -11.5 & -4.4 & 3.6 \\
\hline & $\operatorname{Ln}(B s b l)=-0.77+0.06 * D B H+0.85 * \operatorname{Ln}(H)+0.68 * \operatorname{Ln}(c a)$ & 0.97 & 0.04 & 0.05 & -9.6 & -2.6 & 3.8 \\
\hline & $\operatorname{Ln}(B s b l)=-1.37+0.99 * \operatorname{Ln}(D B H)+0.74 * \operatorname{Ln}(\mathrm{ca})$ & 0.97 & 0.04 & 0.05 & -6.1 & -0.5 & 4.1 \\
\hline & $\operatorname{Ln}(B s b l)=-1.75+0.76 * \operatorname{Ln}(c a)+1.06 * \operatorname{Ln}\left(D_{30}\right)$ & 0.97 & 0.04 & 0.05 & -5.6 & 0.01 & 4.0 \\
\hline & $\operatorname{Ln}(B s b l)=-0.04+0.07 * D_{30}+0.74 * \operatorname{Ln}(\mathrm{ca})$ & 0.97 & 0.04 & 0.05 & -4.8 & 0.8 & 4.2 \\
\hline \multirow{7}{*}{$\begin{array}{c}\text { Total aerial } \\
\text { (aboveground) }\end{array}$} & $\operatorname{Ln}(B)=-2.01+0.02 * c a+1.73 * \operatorname{Ln}(D B H)+0.82 * \operatorname{Ln}(H)$ & 0.99 & 0.02 & 0.02 & -35.1 & -28.1 & 5.9 \\
\hline & $\operatorname{Ln}(B)=-1.79+0.21 * H+0.02 * c a+1.74 * \operatorname{Ln}(D B H)$ & 0.99 & 0.02 & 0.02 & -34.4 & -27.4 & 5.9 \\
\hline & $\operatorname{Ln}(B)=-2.09+0.02 * \mathrm{ca}+2.05 * \operatorname{Ln}\left(\mathrm{D}_{30}\right)$ & 0.99 & 0.02 & 0.03 & -25.8 & -20.2 & 6.8 \\
\hline & $\operatorname{Ln}(B)=-3.23+2.61 * \operatorname{Ln}\left(D_{30}\right)$ & 0.97 & 0.04 & 0.05 & -7.9 & -3.7 & 1.9 \\
\hline & $\operatorname{Ln}(B)=-3.51+2.67 * \operatorname{Ln}\left(D_{15}\right)$ & 0.97 & 0.05 & 0.06 & -3.0 & 1.2 & 2.4 \\
\hline & $\operatorname{Ln}(B)=-2.21+2.35 * \operatorname{Ln}(D B H)$ & 0.97 & 0.04 & 0.05 & -6.8 & -2.6 & 9.7 \\
\hline & $\operatorname{Ln}(B)=-1.93+1.18 * \operatorname{Ln}(b a)$ & 0.97 & 0.04 & 0.05 & -6.8 & -2.6 & 9.7 \\
\hline
\end{tabular}

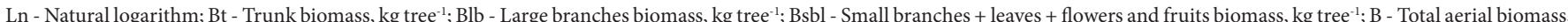
$\mathrm{kg}$ tree ${ }^{-1} ; \mathrm{D}_{15}$ and $\mathrm{D}_{30}$ - Trunk diameter at 15 and $30 \mathrm{~cm}$ above the ground, respectively, $\mathrm{cm} ; \mathrm{DBH}$ - Diameter at breast height, $\mathrm{cm} ; \mathrm{ba}-\mathrm{Basal}$ area, $\mathrm{m}^{2} ; \mathrm{H}-\mathrm{Total}$ height; $\mathrm{ca}-\mathrm{Crown}$ area, $\mathrm{m}^{2} ; \mathrm{R}^{2}$ adj - $\mathrm{R}^{2}$ adjusted; SE - Standard error; MPQE - Mean prediction quadratic error; AIC - Akaike information criterion; BIC - Bayesian information criterion; FI - Furnival Index 
The two best fit models (Figure 2A, C, Table 3) are based on ca, DBH and $\mathrm{H}$. These models express the Ln of total aerial biomass, so the reconversion to biomass values requires the calculation of a correction term.

In both models, the $\mathrm{p}$-values are $\mathrm{p}<0.05$, indicating statistically significant relationships between variables with

A.

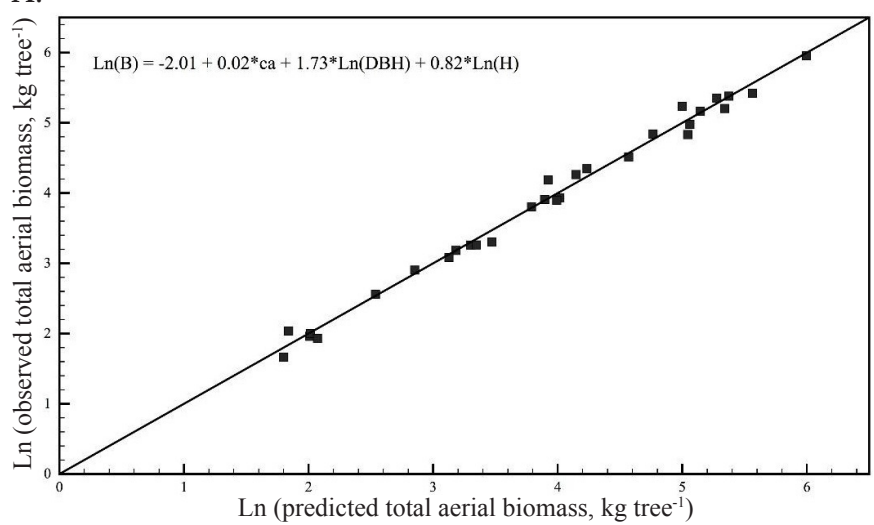

B.

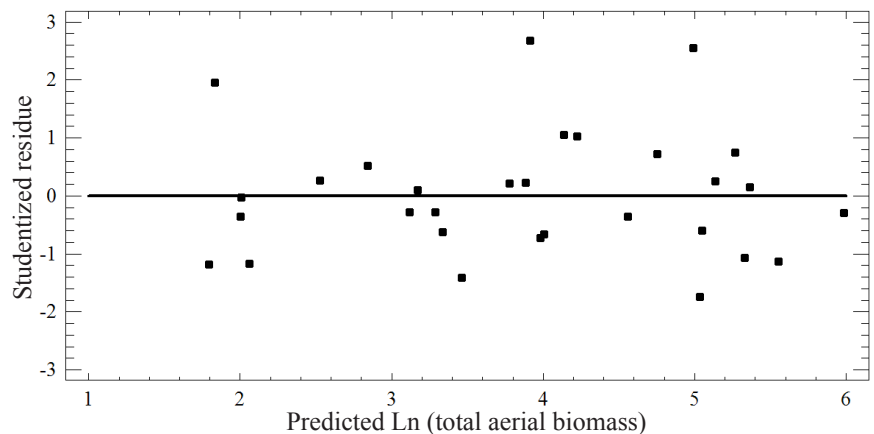

C.

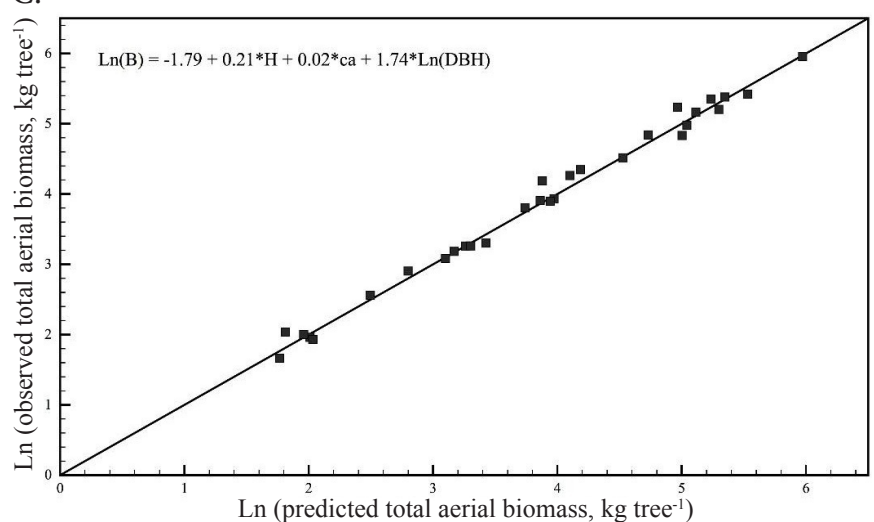

D.

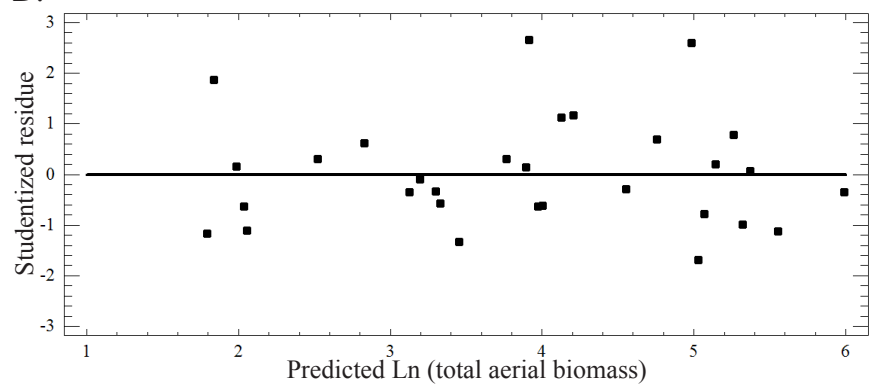

B - Total aerial biomass, $\mathrm{kg}_{\text {tree }}{ }^{-1}$; $\mathrm{ca}$ - Crown area, $\mathrm{m}^{2}$; DBH - Diameter at breast height, $\mathrm{cm}$; and $\mathrm{H}$ - Total height, $\mathrm{m}$

Figure 2. Relationship between predicted and observed total aerial biomass (A and $\mathrm{C}$ ) and corresponding residual plots (B and D) of Prosopis affinis individuals in native forests of Espinal (Entre Ríos, Argentina) a confidence level of $95 \%$. The values of the statistic $\mathrm{R}^{2} \mathrm{adj}$. indicate that the two models explain $99 \%$ of the variability of Ln B. Values of the Durbin-Watson statistic were 1.98 ( $\mathrm{p}=$ $0.4508)$ and $1.99(\mathrm{p}=0.4644)$ for the first and second models, respectively. These values of $\mathrm{p}>0.05$ indicate that there is no serial autocorrelation in residuals with a $95 \%$ confidence level. No bias was observed in the models, as seen in Figures $2 \mathrm{~B}$ and $\mathrm{D}$.

From the models based on a single variable, the one with greatest predictive capacity is the model that expresses $\mathrm{B}$ as a function of $\mathrm{D}_{30}$ (Table 3 ), which shows a $\mathrm{R}^{2} \mathrm{adj} .=0.97$. Figure 3 shows the ability of this model to predict total aerial biomass.

A single parameter model is very interesting given the practicality and precision in diameter determination with respect to other variables such as height, whose records frequently show low precision, especially in dense forests (Segura Madrigal \& Andrade Castañeda, 2008). The importance of models based on trunk diameter also lies in the fact that this variable is routinely determined in forest inventories, for which sufficient information is available to apply these models. The model based on $\mathrm{D}_{30}$ is very useful for its application in individuals with bifurcated trunks below $1.30 \mathrm{~m}$, a characteristic frequently observed in P. affinis.

The results obtained in this work indicate that models that combine the variables ca, $\mathrm{DBH}$ and $\mathrm{H}$ have the best fit to estimate the aerial biomass of the evaluated species. However,

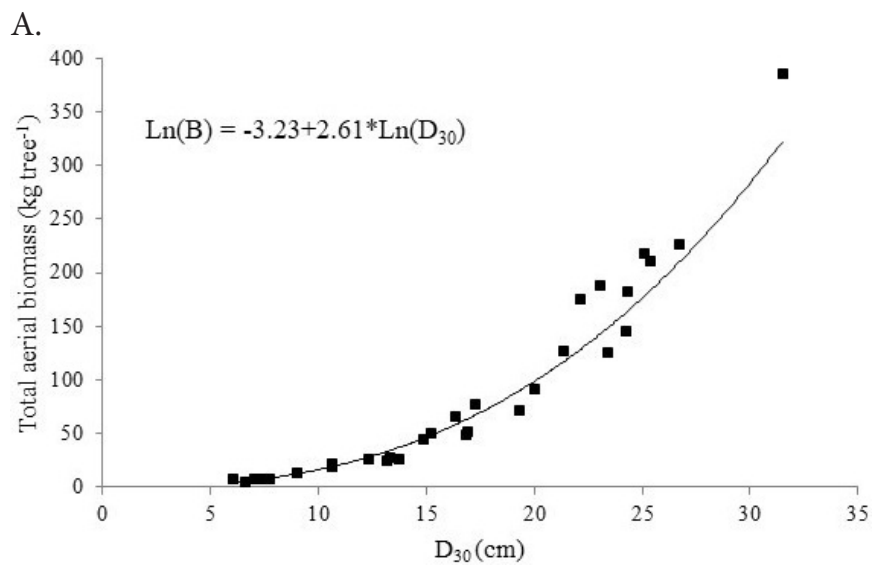

B.

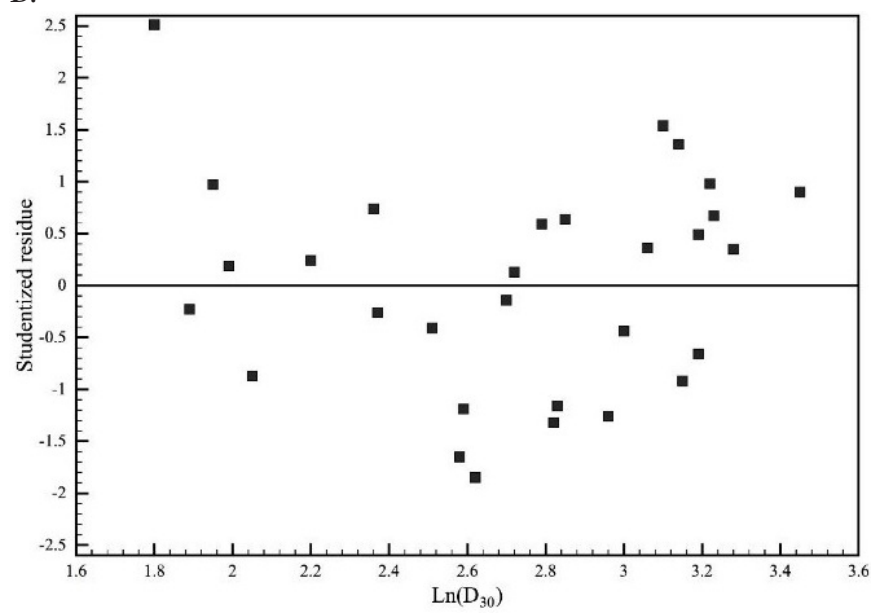

$\mathrm{B}$ - Total aerial biomass, $\mathrm{kg}_{\text {tree }}{ }^{-1}$; and $\mathrm{D}_{30}$ - Trunk diameter at $30 \mathrm{~cm}$ above the ground, $\mathrm{cm}$ Figure 3. Best-fit single-variable model for predicting the total aerial biomass of Prosopis affinis individuals (A), and corresponding residual plots (B) 
considering that it is appropriate to make a balance between statistical rigor and practicality in the use of allometric models, in addition to the fact that height estimates do not usually result in greater precision, the model based on $\mathrm{D}_{30}$ is considered very useful for the prediction of aerial biomass of $P$. affinis.

Conti et al. (2008) propose the trunk diameter measured at the base as the best estimator of economic and aerial volume of Prosopis nigra var. ragonesei individuals in Espinal Santa Fe forests (Argentina). Iglesias \& Barchuk (2010) developed models for P. flexuosa and P. torquata in the Arid Chaco region of Argentina, and those models using the square of trunk diameter at the base were the models with a better performance, while the incorporation of total height as a regressor did not produce improvements in biomass prediction. On the other hand, Risio Allione (2012) determined functions to estimate the total individual biomass of $P$. caldenia, selecting basal area and total height as the best predictor variables. In this work, the model based on basal area has a good predictive capacity of total biomass, although it does not provide the best fit (Table 3).

Several studies propose $\mathrm{DBH}$ as the best estimator of forest volume and biomass. Husch et al. (1971) affirm that the DBH is the best variable to estimate the forest volume of species in general. In the Arid Chaco region, Gaillard de Benítez et al. $(2010,2014)$ also observed that DBH was the variable having the highest correlation with individual aerial biomass of $P$. nigra and A. quebracho-blanco.

The variables ca, $\mathrm{DBH}$ and $\mathrm{H}$ were the best estimators of large branches biomass (Blb) and the small branches + leaves + flowers + fruits biomass (Bsbl). These models have coefficients $R^{2}$ adj. $\geq 0.97$ (Table 3 ). In all cases, the parameters or coefficients of the selected models were significant $(\mathrm{p}<0.05)$.

Two models based on a single variable $\left(\mathrm{DBH}\right.$ and $\left.\mathrm{D}_{30}\right)$ also had good fits to estimate large branches biomass (Table 3), with $\mathrm{R}^{2} \mathrm{adj} . \geq 0.96$. Both models express the $\mathrm{Ln} \mathrm{Blb}$ as a function of the natural logarithm of $\mathrm{DBH}$ and $\mathrm{D}_{30}$.

Models with the highest predictive capacity of trunk biomass $(\mathrm{Bt})$ use diameters $\left(\mathrm{D}_{30}, \mathrm{D}_{15}\right.$, ba and $\left.\mathrm{DBH}\right)$ transformed by the natural logarithm as independent variables, presenting the best values of the parameters used for selection (Table 3 ). Of these models, the one that explains the Ln of biomass as a function of $\operatorname{Ln} D_{30}$ was the one with the highest adjustment.

Selected models to predict biomass by component present good adjustment and precision, both for trunk and fractions that include branches and leaves. This result differs from those reported in the literature, where the models to predict the biomass of branches and leaves result from less adjustment and precision than those developed for trunk and total biomass. This happens because Blb and Bsbl are more influenced than the trunk by competition conditions, water regimes and tree density, thus presenting higher variability (Andrade Castañeda et al., 2018).

Allometric models are critical tools for such a purpose and have the potential to improve our understanding of carbon sequestration in woody vegetation, to support the implementation of policies and mechanisms designed to mitigate climate change (Agrawal et al., 2011), to calculate costs and benefits associated with forest carbon projects and to promote sustainable forest management (Henry et al., 2013).
The development of accurate allometric models to determine tree biomass and its reduction associated with deforestation and degradation of native forests allows the study of carbon flows in the different regional patterns of soil use.

\section{Conchusions}

1. The best total aerial biomass models for P. affinis were based on crown area, breast height diameter and total height. The best fit model was:

$\operatorname{Ln}(B)=-2.01+0.02 * \mathrm{ca}+1.73{ }^{*} \operatorname{Ln}(\mathrm{DBH})+0.82{ }^{*} \operatorname{Ln}(\mathrm{H})$.

2. The single model $\operatorname{Ln}(B)=-3.23+2.61 * \operatorname{Ln}\left(D_{30}\right)$ also has a very good predictive capacity of aerial biomass, resulting in a simple model of great practicality for its application in individuals of bifurcated trunks below $1.30 \mathrm{~m}$.

3. The biomass expansion factors values varied between 2.25 and 5.28, and were significantly higher in individuals with larger diameters.

4. Due to the high quality of the estimated data, the models found in this work are useful for predicting aerial biomass nondestructively and represent a valuable tool for improving carbon estimates in Espinal native forests.

\section{ACKNOWLEDgements}

This work was funded in the framework of the research project PID UNER 2182 "Stock of carbon in native arboreal species of Espinal (Entre Ríos)”. We are grateful to I. Carpp (UNER) and C. Rausch (Aldea Santa María, Entre Ríos) for their help in field work.

\section{Literature Cited}

Agrawal, A.; Nepstad, D.; Chhatre, A. Reducing emissions from deforestation and forest degradation. Annual Review of Environment and Resources, v.36, p.373-396, 2011. https://doi. org/10.1146/annurev-environ-042009-094508

Andrade Castañeda, H. J.; Segura Madrigal, M. A.; Feria, M.; Suárez, W. Above-ground biomass models for coffee bushes (Coffea arabica L.) in Líbano, Tolima, Colombia. Agroforestry Systems, v.92, p.775-784, 2018. https://doi.org/10.1007/s10457-016-0047-4

Andrade Castañeda, H. J.; Segura Madrigal, M. A.; Forero, L. A. Desarrollo de modelos alométricos para volumen de madera, biomasa y carbono en especies leñosas perennes: Conceptos básicos, métodos y procedimientos. Ibagué: Universidad del Tolima, 2014. 48p.

Bautista-Hernández, J.; Torres-Pérez, J. A. Valoración económica del almacenamiento de carbono del bosque tropical del ejido Noh Bec, Quintana Roo, México. Revista Chapingo, v.9, p.69-75, 2003.

Cabrera, A. L. Regiones fitogeográficas argentinas. 2.ed. Buenos Aires: ACME, 1976. 85p.

Conti, G.; Coirini, R.; Zapata, R. Funciones de estimación de volumen de P. nigra var. ragonesei (Algarrobo Amarillo) en un Bosque del Espinal Santafesino. Ciencia, v.3, p.39-51, 2008.

Domínguez-Cabrera, G.; Aguirre-Calderón, O. A.; Jiménez-Pérez, J.; Rodríguez-Laguna, R.; Díaz-Balderas, J. A. Biomasa aérea y factores de expansión de especies arbóreas en bosques del sur de Nuevo León. Revista Chapingo, v.15, p.59-64, 2009. 
Furnival, G. M. An index for comparing equations used in constructing volume tables. Forest Science, v.7, p.337-341, 1961.

Gaillard de Benítez, C.; Pece, M.; Juárez de Galíndez, M.; Acosta, V. H. Modelaje de la biomasa aérea individual y otras relaciones dendrométricas de Prosopis nigra Gris. en la provincia de Santiago del Estero, Argentina. Quebracho, v.22, p.17-29, 2014.

Gaillard de Benítez, C.; Pece, M.; Juárez de Galíndez, M.; Maldonado, A.; Acosta, V. H.; Gómez, A. Biomasa aérea de ejemplares de quebracho blanco (Aspidosperma quebracho-blanco) en dos localidades del Parque Chaqueño Seco. Quebracho, v.9, p.115127, 2010.

Gyenge, J.; Fernández, M. E.; Sarasola, M.; Urquiza, M. de; Schlichter, T. Ecuaciones para la estimación de biomasa aérea y volumen de fuste de algunas especies leñosas nativas en el valle del río Foyel, NO de la Patagonia argentina. Bosque, v.30, p.95-101, 2009. https://doi.org/10.4067/S0717-92002009000200005

Henry, M.; Bombelli, A.; Trotta, C.; Alessandrini, A.; Birigazzi, L.; Sola, G.; Vieilledent, G.; Santenoise, P.; Longuetaud, F.; Valentini, R.; Picard, N.; Saint-André, L. GlobAllomeTree: International platform for tree allometric equations to support volume, biomass and carbon assessment. iForest - Biogeosciences and Forestry, v.6, p.326-330, 2013.

Husch, B.; Miller, C. I.; Beers, T. W. Forest mensuration. 2.ed. New York: John Wiley \& Sons, 1971. 410p.
Iglesias, M. del R.; Barchuk, A. H. Estimación de la biomasa aérea de seis leguminosas leñosas del Chaco Árido (Argentina). Ecología Austral, v.20, p.71-79, 2010.

IPCC - Intergovernmental Panel on Climate Change. Climate Change 2014: Synthesis report - Contribution of working groups I, II and III to the Fifth Assessment Report of the Intergovernmental Panel on Climate Change. Geneva: IPCC, 2014. 151p.

Risio Allione, L. Cuantificación de biomasa y carbono en bosques nativos de Prosopis caldenia (Burkhart) en la Pampa semiárida Argentina. Palencia: Universidad de Valladolid, 2012. 71p. Doctoral Thesis

Sabattini, R. A.; Sione, S. M. J.; Ledesma, S. G.; Sabattini, J.; Wilson, M. G. Estimación de la pérdida de superficie de bosques nativos y tasa de deforestación en la Cuenca del Arroyo Estacas (Entre Ríos, Argentina). Revista Científica Agropecuaria, v.20, p.45-56, 2016.

Segura Madrigal, M. A.; Andrade Castañeda, H. J. ¿Cómo construir modelos alométricos de volumen, biomasa o carbono de especies leñosas perennes? Agroforestería de las Américas, v.46, p.89-96, 2008.

Somogyi, Z.; Cienciala, E.; Mäkipää, P.; Muukkonen, P.; Lehtonen, A.; Weiss, P. Indirect methods of large scale forest biomass estimation. European Journal of Forest Research, v.3, p.11-13, 2006.

StatPoint Technologies Inc. Statgraphics Centurion. Warrenton: StatPoint Technologies Inc., 2010. sp. 